\title{
8
}

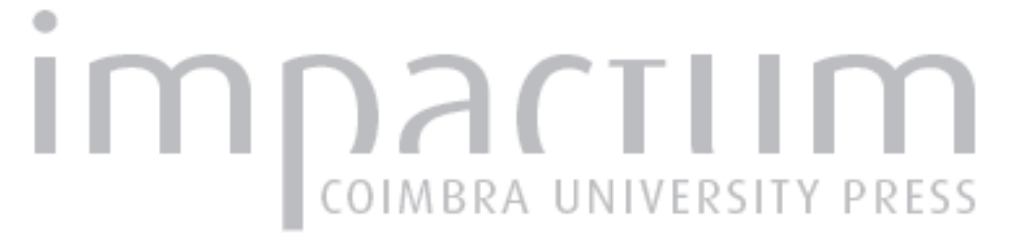

\section{Acção, pensamento e futuro}

Autor(es): $\quad$ Tavares, Gonçalo M.

Publicado por: Imprensa da Universidade de Coimbra

URL persistente:

URI:http://hdl.handle.net/10316.2/43079

DOI:

DOI:http://dx.doi.org/10.14195/0870-4112_3-3_11

Accessed : $\quad$ 26-Apr-2023 12:10:47

A navegação consulta e descarregamento dos títulos inseridos nas Bibliotecas Digitais UC Digitalis, UC Pombalina e UC Impactum, pressupõem a aceitação plena e sem reservas dos Termos e Condições de Uso destas Bibliotecas Digitais, disponíveis em https://digitalis.uc.pt/pt-pt/termos.

Conforme exposto nos referidos Termos e Condições de Uso, o descarregamento de títulos de acesso restrito requer uma licença válida de autorização devendo o utilizador aceder ao(s) documento(s) a partir de um endereço de IP da instituição detentora da supramencionada licença.

Ao utilizador é apenas permitido o descarregamento para uso pessoal, pelo que o emprego do(s) título(s) descarregado(s) para outro fim, designadamente comercial, carece de autorização do respetivo autor ou editor da obra.

Na medida em que todas as obras da UC Digitalis se encontram protegidas pelo Código do Direito de Autor e Direitos Conexos e demais legislação aplicável, toda a cópia, parcial ou total, deste documento, nos casos em que é legalmente admitida, deverá conter ou fazer-se acompanhar por este aviso. 


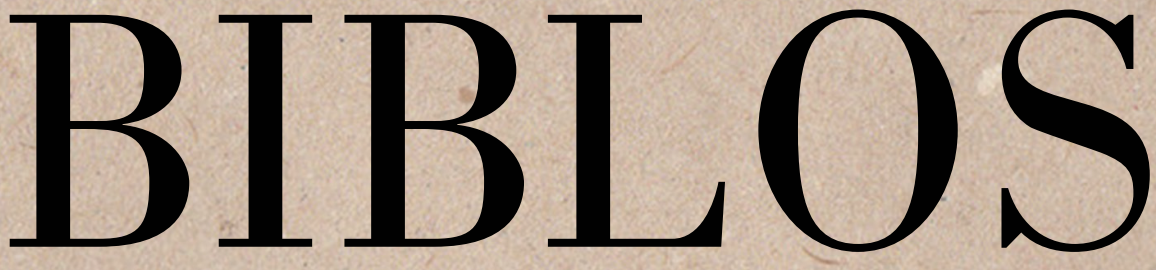

Revista da Faculdade de Letras da Universidade de Coimbra

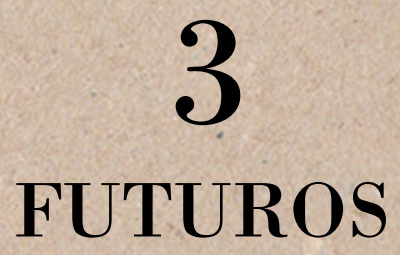

NÚMERO 3, 2017

3. ' SÉRIE 


\section{Cruzamentos}

GONÇALO M. TAVARES 


\title{
ACÇÃO, PENSAMENTO E FUTURO
}

\author{
Action, thought and the future \\ GONÇALO M. TAVARES \\ caminho@editorialcaminho.pt \\ Associação Portuguesa de Escritores
}

DOI
https://doi.org/10.14195/0870-4112_3-3_11

Recebido em setembro de 2016

Aprovado em dezembro de 2016

Biblos. Número 3, 2017 • 3. a Série

pp. $225-226$ 
1. Valéry escreveu algumas páginas importantes sobre o histórico encontro entre Napoleão, símbolo do "império fundado sobre a inteligência em acção", e Goethe, símbolo do império "da inteligência em estado de liberdade". E que também foi o encontro entre o poder e a cultura. Desse encontro saíram as célebres palavras de Napoleão a Goethe: "Você, é um Homem", numa demonstração do respeito que a Pura acção - Napoleão - ainda assim guarda pelo Puro pensamento.

Claro que esta divisão entre acção-pensamento é sempre um pouco artificial e forçada - o próprio Valéry escreveu que "não existe teoria que não seja um fragmento, cuidadosamente preparado, de alguma autobiografia”. Ou seja, a teoria - a organizaçáo do pensamento - tem uma ligaçáo fortíssima e inabalável, às acções sucessivas que, a certa distância, formarão aquilo a que chamamos biografia de uma pessoa.

2. Por outro lado, conhecimento e possibilidade de acção estão muitas vezes afastados, separados, quase como se fossem inimigos.

Um exemplo literário. Num sonho ficcional em redor das teorias de Einstein, o escritor Alan Lightman apresenta uma espécie de vagabundos que têm a particularidade de conhecer já o futuro. Um desses viajantes que vem do futuro "é obrigado a assistir aos acontecimentos sem neles tomar parte, sem neles interferir".

Sabe o que vai acontecer (tem um conhecimento excepcional, sabe a mais), mas nada pode alterar (está desprovida de acção). E eis o que sucede: esse viajante sente "inveja das pessoas que vivem no seu próprio tempo, que podem agir livremente, sem pensar no futuro...”.

Ele, o viajante do futuro, aquele que tem uma informação privilegiada, não pode agir, em suma: "Perdeu a sua personalidade".

O importante neste pequeno conto é a relevância dada ao agir relativamente ao conhecer.

De facto, no futuro certamente saberemos mais - enquanto indivíduos e enquanto colectivo. Porém, isso não é o essencial.

No futuro vamos conseguir agir mais? - eis a questão central. 